\title{
Autosomal recessive limb-girdle muscular dystrophy type 2C
}

INSERM

\section{Source}

INSERM. (1999). Orphanet: an online rare disease and orphan drug data base. Autosomal recessive limb-girdle muscular dystrophy type 2C. ORPHA:353

Autosomal recessive limb-girdle muscular dystrophy type 2C (LGMD2C) is a subtype of autosomal recessive limb-girdle muscular dystrophy characterized by a childhood onset of progressive shoulder and pelvic girdle muscle weakness and atrophy frequently associated with calf hypertrophy, diaphragmatic weakness, and/or variable cardiac abnormalities. Mild to moderate elevated serum creatine kinase levels and positive Gowers sign are reported. 